\title{
Union leadership in UK social housing
}

\author{
David Preece and Carolyn Ward \\ Leadership \& Organisational Development Journal (2012), Vol. 33, No. 8, pp.763-778.
}

\section{Purpose}

The paper examines the impact of the privatisation and restructuring of social housing provision upon union leadership in the sector. We explore how local union leaders have adapted to radical reforms in the nature and organization of social housing provision in the UK.

\section{Design/methodology/approach}

The paper draws upon empirical material collected by the authors from social housing associations, informed by the union leadership literature and Habermas' (1987) concepts of 'communicative action' and 'colonization', drawing in particular upon the recent work of Edwards (2009).

\section{Findings}

There are indications of moves to a more formalised relationship between management and local union leaders/ staff representatives, with management keen to promote more 'openness, partnership and collaboration' in working with the union leaders and staff reps. There was some evidence of senior managers involving local union leaders at earlier stages of policy and procedural initiatives, and of senior managers being more explicitly incorporated in the management-union leader nexus.

\section{Research limitations/implications}

Given the limited amount of research to date on union leadership in social housing organizations, and the exploratory nature and limited scope of our study (which, to the best of our knowledge, is the first to look at these matters), it follows that we still have limited knowledge of practice. Amongst other considerations, it is necessary to broaden the scope of future studies to take in a larger number of UK social housing providers, and to gather data from union/ staff association members as well as managers and local union leaders.

\section{Originality/value}

The paper examines a matter which has been neglected by researchers to date, that is the changing nature and role of union leadership in social housing organizations, and it does this through an examination of the changing intra- organizational contexts within which this is taking place.

Keywords: social housing, union leadership, organizational change, communicative spaces/action.

Type of paper: research 


\begin{abstract}
The paper examines the impact of the privatisation (Gruis and Nieboer, 2003) and restructuring of social housing provision upon union leadership in the sector. Greene et al (2000: 75) claim that 'the extent to which unions are affected by changes in the wider environment beyond the workplace can depend on the nature of members' attitudes towards the union', and that one of the main influences here is the leadership style adopted by union leaders. We explore how local union leaders have adapted to radical reforms in the nature and organization of social housing provision in the UK. The paper outlines and discusses the above changes and developments, and draws upon empirical material collected by the authors from social housing associations to consider the impact they have had upon union leadership in the sector, informed by the union leadership literature and Habermas' (1987) concepts of 'communicative action' and 'colonization', drawing in particular upon the recent work of Edwards (2009).
\end{abstract}




\section{INTRODUCTION}

The core purpose of a social housing $(\mathrm{SH})$ organization is to provide accommodation and related services to those in society who are most at risk and the most vulnerable (Sprigings, 2002). Until around the last decade, this came from municipal housing departments under the control of local authorities. Walker (2001) predicted that we will see the extinction of this form of provision by 2015 , due in the main to governments preferring delivery to come from housing associations (now called Registered Social Landlords). Recently, the sector has experienced extensive merger activity (Mullins and Craig, 2005) and the emergence of 'not-for-profit' housing associations. The impact of these changes on the organizations and people working in the sector has been underresearched, including the union/employee representation, managerial and governance arrangements and processes which have emerged. In the New Public Management literature these new social housing providers are depicted as risk taking and more innovative/entrepreneurial than they were when in the public sector, driven by a private sector ethos and culture (Kirkpatrick et al, 2005), leading Collier (2005) to call them the 'social businesses of the future'.

The theme of leadership is commonly at the heart of reform agendas (Van Wart, 2003), as we have found it to be in the social housing sector, and this raises the question of how union leadership has also changed in response to the sort of developments outlined above. Our findings from some social housing providers in the North East of England indicates that there is quite a degree of variation within the sector, including unions continuing to be recognized in the new governance arrangements, union recognition being reviewed by 
employers, and unions being de-recognised with (following the merger of a number of housing providers) the employees opting to join a non-union staff consultative council. Trade union leadership as a theme is a relatively unexplored area within the more general leadership literature, in part as a result of the strong US -dominance here, especially in the earlier writings which came from scholars much more strongly influenced by psychology/social psychology than sociology (see, eg, Bass, 1985, 1990; Burns, 1978; Vroom and Yetton, 1973; Stogdill, 1974). Rather than attempt to draw upon this literature, which even in the more recent sociologically-informed writings still shows a lack of interest in union leadership (see, eg, Jackson and Parry, 2008; Grint, 2005; Storey, 2004), we have focused upon using theorizations of aspects of organization contexts (particularly internal contexts) to situate our empirical material, which is examining union leadership in the new and developing SH governance arrangements we referred to above. Our point of departure here is Edwards' (2009) recent deployment of Habermas' (1987) concepts of 'communicative action' and 'colonization' in a study of challenges currently facing the National Union of Teachers (NUT).

We first outline the changing contexts of social housing, and then outline some historically and contextually-grounded studies of local union leadership and in particular Edwards' (2009) work on the NUT, where she draws upon Habermas' (1987) theory of communicative action and colonization and its implications for union leader and member participation. The methodology is then briefly detailed; this is followed by a presentation of our findings and a concluding discussion.

\section{CHANGE IN THE UK SOCIAL HOUSING SECTOR}


Social housing organisations originated during the nineteenth century (The Housing of the Working Classes Act, 1890), and have as their main objective the provision of accommodation for the most vulnerable in society. These social housing landlords or 'Registered Social Landlords' (RSLs) provide specialised accommodation and related services to those in acute need. The provision of rented accommodation in the UK has undergone radical reform lasting for over 20 years, resulting in concerns about its future (Fitzpatrick and Stephens, 2008); Czischke, 2009; Pawson and Smith, 2009; Ward and Preece, 2010). Changes and the associated challenges have gained momentum in the last decade, encouraged by government policy initiatives, which have pushed for privatisation and a residualised sector (Malpass, 2000; Walker, 2001; Gruis and Nieboer, 2003; Malpass and Victory, 2010). This is being mirrored across parts of Europe (Czischke, 2009). The result has been that the poorest in society have little choice other than to enter the SH sector, with the more affluent taking up owner occupation.

The delivery and management of SH has experienced a chequered history. In the 1970s, large metropolitan borough councils in the UK, comprising of over 100,000 properties and in some cases managed by a workforce of over 2,000 housing management staff, were the main providers, and took on one of two landlord roles: a 'contractual' (Priemus et al, 1999) or 'social welfare' (Clapham et al, 2000) role, the latter being preferred by the professional institute for the sector - The Chartered Institute of Housing (CIH). Following the 1985 Housing Act, in the second half of the 1980s housing associations became the main providers of social housing in the UK (Malpass, 2000). This was at a time when the 'New Public Management' (NPM) was underway as a major programme of public sector reform. Many local councils opted out of the provision of social housing, 
encouraged to pursue one of two routes to achieve this: (i) 'tenure transfer'(Harriott and Mathews, 1998, 2009), which could be tenant- initiated or landlord- initiated; either way, the outcome was the same- the parties moved away from their current tenure with the local authority; (ii) via 'Large Scale Voluntary Transfer'(LSVT), ie the transfer of local authority staff and property from the direct management and control of the local authority to an external organization.

In the late 1980s the landlord role moved towards that of a 'comprehensive housing service', with estate- based offices and staff. This form of decentralised provision brought with it a tendency for staff to 'become less specialised, with the development of generic, or multi skilled housing officers' (Harriott and Matthews, 1998: 211) and raised questions about the 'social' role expected of these new organisational forms (Collier, 2005). More recently, interest has focused on how the new SH providers are wrestling with their social remit whilst being exposed to competition in the SH marketplace. Bradley (2008) has noted that the skills, knowledge and competencies of employees have been reformulated within these 'market-sensitive companies' (2008: 883). Pawson and Smith (2009) found that attitudes had changed in the sector, but that the new governance arrangements have had a 'mixed response' in these more commercially-oriented organisations.

The last 20 years or so of change have resulted in a SH sector possessing a high degree of variation and complexity, operating in a continually-changing environment (Ward et al, 2010), with a new regulatory body, the Tenancy Services Authority (TSA), and resulting in social housing being one of the most highly regulated sectors alongside financial services. The TSA was set up following the Housing and Regeneration Act, 2008, and its 
full powers came into force in April, 2010; however it will face abolition in 2012. It claims that it will safeguard the $£ 127$ billion public investment in the sector, along with the rights of over 8 million people living in the 4 million 'affordable homes' provided by social housing landlords in the UK.

It seems reasonable to hypothesise that the move away of SH provision from the local authorities to private sector organizations will have had an impact on employee 'voice' and the nature and form of collective and union membership and leadership. Commercialism is now central to SH provider operations, and, for example, call centres are being developed/opened, driven by a customer service philosophy, along with the more widespread use of information technology in the day to day delivery of services. Yet, there exists little empirical research on these issues, with the debate 'dominated at one level by a macro-level polemic associated with the so-called 'New Public Management', and at another by assertions about the 'new managerialism' to be found in the sector' (Ward and Preece, 2010: 8). The key concern of this paper is to address this lacunae via a theoretically-informed empirical investigation of what is going on in the sector. Before we outline our methodology and findings, however, it is important to outline the theoretical grounding of the empirical analysis.

\section{UNION LEADERSHIP: (CHANGING) SPACES AND CONDITIONS}

In recent years, there have been some historically and contextually-grounded studies of local union leadership, where both the historical development of given unions and/or the wider social, political and economic and/or intra-organizational contexts of membership are seen as influencing the nature and form of local union leadership-in other words, as 
generating and providing contexts for action. Knowles (2007), for example, in a study of national union leadership, developed biographical case studies of five national leaders of the Australian Workers' Union between 1886-1972, and illustrated the significance of historical context, as well as 'how leadership and the organization's environment interconnect to shape the way unions develop over time...' (2007: 191). He comments (p196): '...analysing leaders at critical junctures and major turning points in the organization's development can assist in understanding the role of the individual in institutional change'. This helps correct for 'the over-emphasis of a structural determinist approach... [which] has led to a general neglect of the importance of officials' own values in shaping their perceptions and conduct' and 'the ahistorical nature of much of the literature...' on union leadership (2007: 193, drawing upon Kelly and Heery, 1994). At the same time, researchers should not neglect the influence of union leader interpretations, preferences and behaviour (Knowles, 2007; Theakston, 1997), not least because:

Union leaders have a vested interest in retaining a viable membership base. In this respect, trade unions face similar competitive challenges as their private sector counterparts. Members can choose to not belong to a trade union or in some cases join another union which they perceive as more likely to meet their expectations. So union leaders need to demonstrate they can achieve [union] organizational objectives. . .to ensure they are seen by their stakeholders as effective organizational leaders (Knowles, 2007: 206).

It should be added here that in examining local union leadership behaviour, in addition to locating this in the history of the particular unions concerned, the local and wider contexts of action, and the values, preferences and actions of the local leaders, account 
should also be taken of the local union members' orientations, beliefs and willingness to participate in union activities and actions (Metochi, 2002), somewhat analogous to the current talk in the organizational leadership literature about 'followership' (see, eg, Collison, 2005; Meindl et al, 2004; Shamir et al, 2007; Riggio et al, 2008; Ago, 2009). It is interesting to note, however, that Hickey et al (2010), in a recent study of member activism and union organizing and renewal, found that 'strategic and institutional' factors were central in explaining the source of bargaining power, rather than member activism, which was critical in some, but by no means all efforts at union renewal. Another example of a historically and contextually-grounded study of local union leadership comes from the work of Greene et al (2000). This was a longitudinal case study of union leadership in two organizations, looking in particular at how the local union leaders conducted their role and the influence of their leadership style on the commitment and participation of the members. Interviews were carried out with 20 shop floor employees in one company and 19 in the other, with the convenors and their immediate predecessors at both companies, and with the full time officers and nine managers at one company. The authors identified a dialectical relationship between the local union leaders and members with regard to union democracy and the local 1eadership style. They devote a good deal of attention to the local contexts as:

... the attitudes of the workers described and the attitudes and actions of the union leaders must be set against the ideological traditions of the industry, the specific product, and labour market pressures and resultant management strategies motivating change or continuity in industrial relations.(Greene et al, 2000: 78). 
They found that 'While union structures were similar at the two companies, the ways in which the convenors, stewards and members interpreted their roles and performed within those structures differed between the two firms.' (2000: 85). This was in part due to differences in contemporary processes of union organization and local and historical traditions of union organization, and in part due to differences in [union] leadership style between the two companies (whilst, they note, the two companies were very similar in many ways).

Cunningham and James (2010), in a study of union renewal in the UK outsources social care sector, have argued 'in seeking to revitalize themselves, unions, at least in certain contexts, cannot rely on workplace organizing alone' (2010: 35), as:

...there is a need for unions to confront the challenge of becoming 'portfolio planners' in the sense of utilizing a range of 'tailored', contextually orientated approaches which are likely to embody different balances between 'top-down' and 'bottom-up' dynamics and between workplace/organization and 'extraenterprise' focused actions $(2010 ; 40)$.

Cregan et al (2009) is another study which draws upon empirical material (a questionnaire survey of around 1,000 members of an Australian union. See also Twigg et $a l, 2008)$. It attempts to tease out the impact of members' social identification with other members and the transformational leadership of a local union representative upon the collectivism of members during a union mobilization campaign in 2004. As far as the transformational leadership literature is concerned, the authors draw upon the work of a number of authors in this field (including Burns,1978; Bass, 1999; Avolio et al, 2004, 
Feinberg et al, 2005), and argue that the features identified as characterising such leaders are readily applicable to elected union representatives (charisma, emergent from within a group, emotional relationship with the group, and changing the group by articulating a vision for the future). Cregan et al (2009: 705) argue that (local) transformational union leaders:

Encourage the local membership by charismatic, idealistic behaviour, urging their fellow members into struggle by inspirational example. [They] take part in the struggle alongside their fellow unionists, bearing the costs of industrial action. They develop union solidarity and pride in the movement. By these methods, transformational leaders help to transform or change members, and thereby the union itself.

By contrast, transactional leaders 'are servants of bureaucracy, providing short-term material incentives to followers. They are associated with instrumental, goal-oriented behaviour on the part of individual members They are concerned with exchange and reciprocity' (ibid; see also Snape and Redman, 2004). Cregan et al (2010: 713-4), taking a strong psychological turn in discussing their findings, comment that 'the social identification of the individual member with the workplace union and the transformational leadership qualities in the local union representative were associated with the individual member's union loyalty and willingness to work for the union'. They go on to recommend that unions provide training on leadership skills and 'encourage members with transformational qualities to become workplace representatives'. 
As the above authors have argued and shown, then, in studying local union leadership behaviour, it is important to address the local contexts of action, the values, preferences and actions of the local union leaders, and local members' beliefs and willingness to participate in union activities and actions. How might one theorise these local (ie within work organizations) contexts? This is where some of Habermas' (1987) work can be of assistance. As Edwards (2009) has noted, debates on union renewal have either focussed on grassroots strategies for stimulating membership activity or top- down strategies, and 'What is missing from both these approaches is an in-depth exploration of the actual conditions required at the level of the workplace for membership activity to take place' (2009: 443). She also observes that Habermas' (1987) concept of 'communicative spaces' can help us to understand the process of organizing union members in the spaces where discussion and debate takes place between members. These spaces can provide the conditions and opportunities for the building of collective identities and solidarities (Edwards, 2008), and for the creation of consensus and commitment to (union) goals (Carter, 2000).

This focus on community relates to the renewal strategy that Jarley terms 'socialcapital unionism', which highlights how "frequent interactions permit people to know and trust one another, share information, and develop common goals, values and points of view"' (Edwards, 2009: 443; Jarley, 2005: 4).

In his theory of the 'colonization of the lifeworld', Habermas (1987) links the erosion of such communicative spaces to processes of marketization and bureaucratizationprocesses which are, of course, very relevant to the sort of workplaces under consideration in the present paper. Edwards' (2009) paper examines how the restructuring 
of UK state education has affected the National Union of Teachers (NUT), with particular regard to the challenges posed to obtaining an active membership, rather than increasing member numbers per se (which have gone up in recent years). She found that these challenges resulted from the erosion of formal and informal communicative spaces for members; whilst the restructuring had heightened conflict, it had also undermined the conditions upon which the debate necessary for collectivizing this conflict depends. What, then, is the meaning of Habermas' (1987) communicative action and colonization, which 'are inherently related, for in the process of colonization it is the space for communicative action that is eroded' (2009: 445). As Edwards notes, Habermas took the latter from G.H. Mead (1934), 'who stressed the importance of linguistically-mediated, face-to-face 'symbolic interaction' for processes such as socialization, building group solidarity, the transmission of knowledge, and identity formation' (2009: 445). These processes form Habermas' concept of the 'lifeworld':

Communicative action is the medium through which the lifeworld is reproduced on a daily basis. [Here] action has to be carried out 'communicatively', ie through a process of linguistically mediated interaction. Communicative interactions are therefore formed in and through discussion and debate, which has the purpose of achieving a mutual understanding and shared definition of the situation' (Edwards, 2009: 446).

For Habermas, communicative action is thus a distinctive feature of the lifeworld; other areas of society are said to operate upon different principles of action, ie instrumental action organized upon narrow calculations of cost-efficiency. 
This type of rationality is seen by Habermas as characteristic of state-bureaucratic and economic institutions. Here actions are coordinated by money and power, rather than by linguistic communication and mutual understanding... These different forms of rationality are not necessarily in a relationship of conflict or superiority. Technical rationality does, in fact, make the economy and the state far more efficient in their tasks' (Edwards, 2009: 446).

A key problem arises, however, due to the direction of development of modern capitalist societies which has brought these two processes of rationalization into conflict with each another:

This conflict essentially rests upon the fact that the 'system' of technical rationality is growing in order to meet the demands of capitalist markets and states, and in the process of growth, it is intruding into areas of everyday life which are organized communicatively. The concept of the 'colonization of the lifeworld' therefore denotes the situation where the communicative coordination of action is displaced by its technical coordination, either through an extension, or intensification, of markets and state-bureaucracies .... Socialization, group solidarity, and cultural and identity processes depend upon spaces for communicative action and when they are interrupted by attempts to reorganize them on a technical basis, pathological disruptions arise (Edwards, 2009: 446).

Whilst not apparently informed by Habermas' work, Porter and McLaughlin (2006) do address aspects of the circumstances under which (local) organizational action (ie, in this 
case, leadership) takes place; for them there are a range of context components or 'situational factors' (Shamir and Howell, 1999), including organization structuring, culture, climate, and the time dimension.

An organisational context variable refers to one or more elements of the organisation itself that could determine the type of leadership used and/or affect the impact of the leader(s) on their followers/subordinates. (Porter and McLaughlin, 2006: 561).

Porter and McLaughlin (2006) note that writers on leadership have neglected to conceptualise and study the ways in which organizational context can impact upon leadership behaviour and outcomes: leadership in organizations does not occur in isolation and should not be viewed in such a way, thus there is a need for a 'more, sophisticated understanding of how leadership operates within organisational settings' (2006: 574). At the same time, it seems reasonable to assume that leadership can also impact upon and possibly even change aspects of organizational context. The focus in the present paper is upon the former, that is the impact of organizational restructuring and ownership changes on the local union leadership role, but before we move onto discuss these changes in our case study organizations, it is necessary to provide some details relating to our methodology and case companies.

\section{METHODOLOGY}

Data was collected from two SH organizations, which had different histories and had experienced different forms of ownership change and organizational restructuring. The 
research project focussed upon the impact of the changes on the role and work of the local 'union' leaders-union in inverted commas here because in one organization there were no union leaders as such, but rather Staff Consultative Council (SCC) representatives. We were interested in such matters as whether, and if so in what ways, the changes had affected their role, the support they received from the organizations that employed them and how this impacted on their role and relationships within the organization, and any more changes they anticipated in the future.

Semi-structured interviews were conducted, lasting between 40 and 60 minutes, with ten people from the two organizations, four Human Resource specialists and six local union/SCC representatives, the majority of whom had been with the organization throughout the period of restructuring and change (which for one organization was eight years ago and for the other two years). Assurances were given about confidentiality and anonymity. One part of the interviews utilised the critical incident technique, where participants were asked to outline their recollections and experiences of the transition to the new structure and the role they played within the process. The interviews with the union and SCC leaders and HR specialists focused upon how their attitudes and behaviour had changed during and as a result of the restructuring, in terms of three main aspects: the impact of the restructuring on their union role, the support and facilities they were given (if any), and how they saw their role changing in the future. Certain internal organizational documents were also made available by both organizations. All participants agreed to the interviews being tape recorded, and these were subsequently transcribed, in addition to notes being taken during the interviews. For analysis purposes, 
key comments were identified via a coding system which highlighted the major themes to emerge from the interviews.

The case study organizations were Coast and Country Housing (actual name, used with permission) and 'B' Housing Group (not the actual name). Coast and Country Housing $(\mathrm{CCH})$ had a housing stock of just over 10,000 at March $31^{\text {st }}, 2009$. It was established in 2002 to take over the ownership and management of all the housing stock of Redcar \& Cleveland Borough Council, and came about as a result of a ballot of the existing tenants who voted for the transfer. This 'Large Scale Voluntary Transfer' (LSVT) promised substantial investment in the tenants' homes. The organization is a 'not for profit' housing company limited by guarantee, and is a 'Registered Social Landlord' (RSL) regulated by the newly- created Tenant Services Authority (previously, regulation was carried out by the Housing Corporation, which assessed organizations against the requirements of its code of practice). CCH's overall direction and control is the responsibility of a Board of twelve unpaid members supported by four Executive Directors, forming the Senior Executive Team. In July, 2002 employees transferred from Redcar \& Cleveland Council to $\mathrm{CCH}$ on their existing national terms and conditions of employment, and three years later the organization developed its own terms and conditions which were offered to employees on a voluntary basis. Many of the staff transferring from the Council belonged to a trade union (GMB, UNISON, UNITE, or UCAT). At February, 2010, overall union membership was $39 \%$ of the total workforce, with the tradesmen (Direct Labour Organization) being much higher at 75\%. The 'B' Housing Group (BHG), which was formed in 2006 , is the parent holding company of two subsidiary companies- ' $\mathrm{B}$ ' Housing Association (BHA) and 'C' Housing Association (CHA). BHA, a traditional 
Registered Social Landlord, originated in the 1970s, and delivers services to a diverse cross section of people, focusing upon more general needs and supported housing services in order to address the acute needs of vulnerable people in the North East of England; it owns and manages almost 2,000 properties. All three companies have their own governing boards, providing some specialist focus, whilst also complementing each

other's activities in addressing the needs of their local communities. In BHA, prior to the formation of the new group structure in 2006, the Board decided unilaterally what the terms and conditions of employment would be for employees. At best it had an 'informal' approach to staff consultation and held occasional meetings of all staff. CHA transferred its employees and properties under a LSVT from a local council, which recognised UNISON at the time of transfer in 2006. For a 2 year period BHG and BHA organisations had a staff council, while CHA operated with a joint staff and TU staff council. In 2008 all 'B' Housing Group staff chose to opt into a Group Staff Consultative Committee.

\section{FINDINGS}

The presentation of our findings is organised around the three broad themes of (i) the impact of the restructurings on the local union leader/SCC representative role;(ii) the support and facilities provided by management pre and post the restructurings; (iii) how the role is expected to change in the future.

The notation for the interviews is as follows:

$\mathrm{CCH}=$ Coast and Country Housing

BHG= 'B' Housing Group 
$\mathrm{BHA}=$ 'B' Housing Association

$\mathrm{UL}=($ in company) union leader

$\mathrm{HR}=$ Human Resource specialist

The numbers after the interview extracts refer to different people.

\section{Impact of the restructurings on the local union leader/SCC representative role}

A number of changes to the union leader/SCC representative role resulting from the restructurings were identified by the interviewees, and they also provided some interesting comments on the restructuring process itself. The $\mathrm{CCH}$ interviewees commented that there had been some significant changes to the relationship and behaviour between union leaders, union members and management, as illustrated below:

I think if you ask that question to any shop steward, regardless of what union they were in, they would say...that it wasn't such a bad thing to do the transfer, I mean before the transfer took place we were on shaky ground with the council. The government and LA's [Local Authorities] ...didn't get on at the time, funding was stretched, and we had outsourced our gardening section well before our move across...(CCH, UL1)

Through the union role we had to convince people that it was the only road to take at the time, we had meeting after meeting with them, we met at the Town Hall premises and road shows took place... I wouldn't say we went out there and changed everybody's mind, but what we did do is sort of calmed the waters when 
they needed calming as we put into place what was being requested by the company, which was a stable workforce that was able to see both sides of the coin rather than just spinning it from one side. At the beginning it was all hate, hate to us, hate to management, it was unbelievable... Between us the biggest role was calming the waters and saying to people 'We've been to the meetings, we've heard what's been said, what's offered, seen sort of like what the future holds and its up to us to grab it and make the best of it'...If the workforce are honest with you, now they began to trust the company in a way they've never done before... the union reps' involvement in issues now has scaled right down, for the simple reason is that there isn't that two- way anger anymore...It's more open and transparent than it's ever been. The 'them and us' scenario has melted, and not as aggressive as it used to be...It's a cultural change completely. (CCH, UL1) We've had some big issues- one of the main issues in the early days was bonuses, and we had a big input into negotiating rates of pay... in fact I would say the final decision came down to us ...we collected stuff and presented it to the company... and the company agreed. Back in the earlier days certain shop stewards used to react a bit, more shouting and banging on the tables, people used to get up and walk out of meetings. We've come away from that now, and now we sit down and discuss things, but part of that is that management have changed as well; we had some managers that laid the law down, and that's when all the arguments started. Obviously, the management team has been changed over the years...which is good, it's good for us and good for them. (CCH, UL2) 
We are here to work together as opposed to work against each other...the union management relationship changed when [there were] changes to management. $(\mathrm{CCH}, \mathrm{UL3})$

It can be seen from the above that changes had already taken place before the transfer of ownership and that funding was under pressure in the old regime. The union leadership concurred with the management-to-be that the transfer was going to happen and concentrated on convincing its members that this was the case and on getting the best deal for members in the new regime. Now, a few years after the restructuring, the ULs said they had a reduced involvement in everyday organizational matters, yet still a significant one relating to certain key issues for members such as pay. The relationship between the ULs and management is now less confrontational and more discursive, and both the UL and managerial styles have changed in this regard.

BHG has never recognized unions for collective bargaining purposes, as noted earlier. Since the transfer and expansion in size of the organization, the management-SCC relationship has become more structured and formalized, with HR specialists having been appointed to a newly-created HR department in 2006. They have nurtured their working relationships with the SCC reps, who became more proactive, for example with respect to requests for training and development:

It is just a partnership approach, and I think staff see it as that...it does work and there's more of an emphasis over recent years on the HR department ...making 
sure they [SCC reps] are kept up to speed and to work in partnership, and then more commitment from management as well. (BHG, HR1)

A lot of changes happened around the setting up of a HR department [in 2008] ...it was more of an informal type of [consultative] council previously, and the culture change and ...the need to take the responsibility seriously when we've grown so much meant a shift in emphasis on the role of SCC and individuals...they take their responsibilities very seriously now, in that they ask for training, ask for feedback, they go in and query things. And we are more policy orientated than we used to be, everything was informal in these old days. It was very easy to consult with staff, and I think as we've grown we've had to be more methodical to ensure staff representation, and working through with staff as to what shape the SCC forum has got to be for it to be representative...we've allocated a couple of places for BHA, couple of places for $\mathrm{CHA}$, and some for BHG. Previously it was departmental and every department put forward a representative. (BHA, HR1)

Because of the culture of the organization, everyone feels they have a voice ... we used to be a family culture...[we are] now more professional. (BHG, HR2)

\section{Support and facilities pre and post the restructurings}

At $\mathrm{CCH}$, before the ownership change, UL and branch meetings were held at the local Labour Club, and during the early days of the transfer of ownership the $\mathrm{CCH}$ unions 
continued to be formally linked to the relevant local Council trade union branches. Posttransfer, the UL interviewees said that they found themselves to be more isolated from these branches. At the same time, they found $\mathrm{CCH}$ management to be overall more 'supportive' than was the case with the previous regime; management was encouraging all employees (union and non-union staff) to participate in the wider organization through joining working groups, etc.

We used to meet in the Chambers at the Town Hall...once a month to conduct our union business, and the branch meetings took place at [X] Labour Club [which] gave us a room every month free of charge... a lot of our stewards and our membership were involved ...in Labour Party activities...(CCH, UL1)

When we did come over in 2002 we were left under the branch of the Council. I felt that there was little support mechanisms from the unions themselves, that was the worst thing about it, we were out on a limb and left to get on with it basically. $\mathrm{CCH}$ have always done a little bit more I think, always tried to provide support and provide accommodation and time, even though they cut the amount of time down the JTUS [Joint Trade Union Secretary] had when we came over...so I suppose you could say that some support has been taken away. (CCH, UL3)

The company allow me two days a week to do union duties... I've got a computer and we've got a little office... in the depot and the use of a telephone, and all our information is in our files- previous cases or policies... We have a big sort of 
whiteboard with different issues on-going on it, and where we are at and what outcomes. (CCH, UL2)

The company has...opened more opportunities for people to get involved with stuff than Redcar and Cleveland ever did. We have forums...committees, and all sorts of that, where the people on the floor are asked to join. 'Don't let it just be us [management] making the decisions, as you are part of the company and you can make them as well'. Always opportunities for people to put their names down on committees or working forums and working groups...not just to you as union members, but that's to all the actual workforce. (CCH, UL1).

When the pre and post-situation of $\mathrm{CCH}$ is compared with that of BHG in terms of support and facilities for ULs, there was probably less change in the latter case, not least because there had never been any links into union branches and Labour Clubs, etc. Formalization was the order of the day, as referred to in the previous section, and regular meetings were now held between the SCC reps and a member of the senior management team, where briefings were provided on current activities in and plans for the organization:

[SCC reps] ...can use all facilities within the organization, all rooms...just have to ask. We have a lot of staff who dip in and out of focus groups and other areas. (BHG, HR1) 
Because of our open door policy ...'vision and values'- we can approach anybody...these are the old ethos of BHA...important to the organization. (BHG, $\mathrm{SCC} 3)$

[The organization has a] GSMT [Group Senior Management Team]...[and M] is a member of the top. We have a SCC subgroup meeting with him...they tell us what's happening and [what] is expected in the business, so we can prepare. (BHG, SCC 4).

\section{The union leader/SSC representative role in the future}

There was an expectation that the UL role in $\mathrm{CCH}$ would develop into a more 'strategic' one around the policy implementation, whilst the day-to-day role and activity would continue. In BHG there was some indication that the SCC reps were being drawn more into active participation in planning for and responding to inner and outer- organizational change:

[Talking about the UL role in the future] ... more of a stable role, thinking strategically as well as a support role to assist us to go forward. (CCH, HR 1)

We get mini forums where they'll [SCC reps] look at various things, so when we went through a pay and reward review we did have a forum that was looking at the policies, especially the absence management one last year. A couple of the SCC rep's were fantastic on that committee in terms of liaising with 
the staff and making sure that the input to that policy...changing it all around, actually it made the policy what it is today. (BHG, HR1)

Change is just part and parcel of everyday, not just the change in the organization itself, but legislation change...when anything new is happening us SCC reps, we ... will become part of that process. That's how it works now... a subgroup is formed [of] SCC, one or two of us will be part of that and we will feedback into our meetings as before... (BHG, SCC 3).

\section{CONCLUDING DISCUSSION}

In this paper we have examined how the role and orientation of trade union and consultative council leaders in our two social housing organizations has developed over recent years in the wider intra and inter-organizational contexts of ownership changes and restructuring. We focussed upon three particular matters: the impact of the restructurings on the local union leader/SCC representative role, the support and facilities provided by management pre and post- the restructurings, and how the UL/SCC representative role is expected to change in the future. Our key findings can be summarized as follows:

- There has been a move to a more formalised relationship between management and union leaders/staff representatives.

- Management is now more prone to promulgate values such as openness, partnership and collaboration as a basis for its (new/changed) working relationship with ULs/SCC reps. 
- Some indications of senior managers involving ULs and staff representatives at the earlier stages of new/changed policy and procedural initiatives.

- Senior managers appear to be more explicitly incorporated in the management$\mathrm{UL} / \mathrm{SCC}$ representative nexus.

- Overall, the 'on-site' provision for UL/reps' work and meetings between themselves and with members has improved.

It is interesting to compare our findings with those of Pawson and Smith (2009), who in their case studies on the impact of Large Scale Voluntary Transfer on governance arrangements in social housing found that the trade unions played a pivotol role in the restructuring process, and that post the LSVT, senior management involved the union leaders in decision-making and saw them as 'trusted partners' (it is also noteworthy that in the 4-8 years following the transfer of ownership union membership rates fell slightly and then increased). As far as the post-transfer situation is concerned, there is certainly some affinity with our present findings. Of course, it could be argued that much of this is to do with management attempting to incorporate employees in a unitary, 'one-team' view of the organizations for which they work (either as individuals or through their representative bodies), and that the indications here are that, if this has been the case, they have been successful to at least some extent. This can only be a provisional conclusion, as it was not an issue addressed in the present study, and in any event it would be necessary to obtain much more primary data from focussed questions, etc, from a range of stakeholders before any sort of definitive answer could be provided. But we are reasonably confident that we can conclude that the UL and staff representative role has 
changed and that these 'workforce' leaders have become more deeply incorporated into the day-to-day running of these two organizations. Whether the reader sees this as a 'good' or 'bad' thing depends ultimately upon one's political and philosophical perspective. As regards the situation in Coast \& Country Housing, it seems to us that, whilst the facilities provided for ULs on-site have not worsened from the pre-transfer situation, and may actually have improved, the wider location of some of those facilities may be of some significance, that is meetings between ULs, and between ULs and their members previously took place in the local Labour Club, and were linked into the local (Labour) Council. Now they take place on the organization's premises with the support of management.

Drawing upon Habermas' (1987) concept of 'communicative spaces', it can be observed that the main opportunities for ULs to discuss and debate between themselves and for them to hold meetings of their members, have been transferred from a Labour party locale/space to an intra-organizational work space, where it might be anticipated that discussion and debate would be more likely to be infused with work organization/ managerial/ technical issues and considerations, rather than issues relating to the wider labour movement such as resistance and collectivism. This is a matter which, of course, requires a theoretically focussed and empirical-informed research project. Whilst our research has provided some insights into a neglected area, we recognise that much more research needs to be done, not least in capturing the views and orientations of union members about union leadership in the new post-transfer/ restructured workplaces and regimes. 


\section{REFERENCES}

Ago, A. (2009) 'Perspectives of senior level executives on leadership and followership', Journal of Leadership \& Organizational Studies, 16(2), 159-66.

Avolio, B., Zhu, W., Koh, W., Bhatia, P. (2004) 'Transformational leadership and organizational commitment: mediating role of psychological empowerment and moderating role of structural difference', Journal of Organizational Behaviour, 25, 95168.

Bass, B. (1985) Leadership and Performance Beyond Expectations, Cambridge, MA: Harvard University Press.

Bass, B. (1990) Bass and Stodgill's Handbook of Leadership. New York: Free Press. Bradley, Q. (2008). Capturing the Castle: Tenant Governance in Social Housing Companies, Housing Studies, 23(6),879-897.

Bass, B. (1999) 'Two decades of research and development in transformational leadership', European Journal of Work and Organizational Psychology, 8, 9-32. Burns, J. (1978) Leadership, New York: Harper and Row. Carter, B. (2000) 'Adoption of the organizing model in British trade unions: some evidence from manufacturing, science and finance (MSF)', Work, Employment and Society, 14(1), 117-36.

Clapham, D., Franklin, B., and Saugeres, L, (2000). Housing Management: the social construction of an occupational role. Housing, Theory and Society, 17(1),68-82.

Collier, P. (2005) 'Governance and the quasi-public organization: a case study of social housing', Critical Perspectives on Accounting, 16, 929-49.

Collinson, D. (2005) 'The dialectics of leadership', Human Relations, 58(11), 1419-42. 
Cunningham, I. and James, P. (2010) 'Strategies for union renewal in the context of public sector outsourcing', Economic and Industrial Democracy, 31(1), 34-61.

Czischke, D.2009. Managing Social Rental Housing in the EU: A Comparative Study, European Journal of Housing Policy, 9(2), 121-151.

Edwards, G. (2009) 'Public sector trade unionism in the UK: strategic challenges in the face of colonization', Work, Employment and Society, 23(3), 442-59.

Edwards, G. (2008) 'The "Lifeworld" as a resource for social movement participation and the consequences of its colonization', Sociology, 42(2), 299-316.

Feinberg, B., Ostroff, C. and Warner Burke, W. (2005) 'The role of within-group agreement in understanding transformational leadership', Journal of Occupational and Organizational Psychology, 78, 471-88.

Fitzpatrick, S. and Stephens, M. (2008) The future of social housing, London: Shelter. Greene, A-M., Black, J. and Ackers, P. (2000) 'The union makes us strong? A study off the dynamics of workplace union leadership at two UK manufacturing plants', British Journal of Industrial Relations, 38(1), 75-93.

Hickey, R., Kuruvilla, S. and Lakhani, T. (2010) 'No panacea for success: member activism, organizing and union renewal', British Journal of Industrial Relations, 48(1), $53-83$.

Jackson, B. and Parry, K. (2008) A very short, fairly interesting and reasonably cheap book about studying leadership, London: Sage.

Jarley, P. (2005) 'Unions as social capital: renewal through a return to the logic of mutual aid?' Labor Studies Journal, 29(4), 1-26. 
Greene, A., Black, J. and Ackers, A. (2000) 'The union makes us strong? A study of the dynamics of workplace union leadership at two manufacturing plants', British Journal of Industrial Relations, 38(1), 75-93.

Grint, K. (2005) Leadership: Limits and Possibilities, Basingstoke: Palgrave Macmillan. Gruis, V. and Nieboer, N. (2003) 'Strategic housing management: an asset management model for social landlords', Property Management, 22(3), 201-23.

Harriott, S. and Mathews, L. (2009) Introducing affordable housing. Coventry: The Chartered Institute of Housing.

Harriott, S. and Matthews, L. (1998). Social Housing:An Introduction. London: Longman.

Habermas, J. (1987) The theory of communicative action, Volume Two: Lifeworld an $d$ System-The critique of functionalist reason, Cambridge: Polity Press.

Hickey, R., Kuruvilla, S. and Lakhani, T. (2010) 'No panacea for success: member activism, organizing and union renewal', British Journal of Industrial Relations, 48(1), $53-83$.

Kelly, J. and Heery, E. (1994) Working for the union: British trade union officers, Cambridge: Cambridge University Press.

Kirkpatrick, I., Ackroyd, S. and Walker, R. ( 2005) The New Managerialism and Public Service Professions, Basingstoke: Palgrave Macmillan.

Knowles, H. (2007) 'Trade union leadership: biography and the role of historical context', Leadership, 3(2), 191-209.

Malpass, P. and Victory, C. (2010) 'The modernisation of social housing in England', International Journal of Housing Policy, 10(1), 3-18. 
Malpass, P, 2000. The Discontinuous History of Housing Associations in England. Housing Studies.15(2), 195-212.

Mead, G. H. (1934) Mind, Self and Society, Chicago: University of Chicago Press. Meindl, J., Pastor, J. and Mayo, M. (2004) 'Romance of leadership', in G. Goethals, G. Sorenson and J. Burns (eds) Encyclopedia of Leadership, Vol. 3., Thousand Oaks, CA: Sage, 233-45.

Metochi, M. (2002) 'The influence of leadership and member attitudes in understanding the nature of union participation', British Journal of Industrial Relations, 40(1), 87-111. Mullins, D. and Craig, L. (2005) 'Testing the climate: mergers and alliances in the housing associations sector', National Housing Federation, www.curs.bham.ac.uk Pawson, H and Smith, R (2009).Second Generation Stock Transfers in Britain: Impacts on Social Housing Governance and Organisational Culture. European Journal of Housing Policy, 9(4),411-433.

Porter, W. L., and McLaughlin G, B.(2006).’Leadership and the organizational context:Like the weather ?". The Leadership Quarterly, 17, 559-576.

Priemus, H., Dieleman, F. and Clapham, D. (1999), “ Current developments in social housing management”, Journal of Housing and the Built Environment, Vol. 14(3),211-24.

Riggio, R., Challeff, I. nad Lipman-Blumen, J. (2008) How great followers create great leaders and organizations, San Francisco: Wiley.

Shamir, B., Pillai, R., Bligh, M. and Uhl-Bien, M. (eds) (2007) Follower-centered perspectives on Leadership, Greenwich, CT: Information Age Publishing, ix-xxxix. 
Snape, E. and Redman, T. (2004) 'Exchange or covenant: the nature of the memberunion relationship', Industrial Relations, 43, 855-73.

Sprigings, N. (2002) 'Delivering public services under the new public management: the case of public housing', Public Money and Management, Oct-Dec.

Stogdill, R. (1974) Handbook of Leadership, New York: Free Press.

Storey, J. (ed) (2004) Leadership in Organizations: Current Issues and Key Trends, London: Routledge.

Theakston, K. (1997) 'Comparative biography and leadership in Whitehall', Public Administration, 75, 651-67.

Twigg, N., Fuller, J. and Hester, C. (2008) 'Transformational leadership in labor organizations: the effect on union citizenship behaviors', Journal of Labor Research, 29, $27-41$.

Van Wart, M. (2003) 'Public sector leadership theory: an assessment', Public Administration Review, 63(2), 214-28.

Vroom, V. and Yetton, P. (1973) Leadership and Decision-making, Pittsburgh:

University of Pittsburgh Press.

Walker, R. (2001) 'How to abolish public housing: implications and lessons from public management reform', Housing Studies, 6(5), 675-96.

Ward, C., Blenkinsopp, J. and McCauley-Smith, C. (2010). 'Leadership development in social housing: a research agenda', Journal of European Industrial Training, Vol.34(1), $38-53$. 
Ward, C. and Preece, D. (2010) 'The changing nature of social housing: a contextualprocessual approach', New Zealand Journal of Human Resource Management, Vol. 10 (1), 4-12. 